\title{
Implementation of Moral Religion in Education in Majalengka, Indonesia
}

\author{
Sarbini \\ UIN Sunan Gunung Djati Bandung, Indonesia \\ Email: sarbini@uinsgd.ac.id
}

\begin{abstract}
This article seeks to explain how the implementation of moral education is presented at elementary level schools in the midst of community conditions that have changed from an agricultural community to an industrialized society. This study aims to understand how the cognition, affection, and psychomotor aspects of students in the implementation of religious moral values are presented in schools. This research uses qualitative methods with a descriptive approach. Data collection techniques taken were observation, interviews with students from elementary level schools in Cidenok Village, Sumberjaya District, Majalengka Regency. This study found that the moral values of religion presented in schools are still transfer of knowledge and religion in the cognitive aspects, only a small part is in the affective and psychomotor aspects. Second, the socio-economic conditions of the family are part of the background for moral value education which is not optimally absorbed into the affective and psychomotor aspects. Third, the condition of the social environment has a big role in shaping student orientation, where the moral values of religion do not become the control lines for students in carrying out social interactions in society. This study concludes that the implementation of religious moral values in education in schools has a clash with family awareness in supporting education, learning models that are still limited to transfer of knowledge, and the social environment of society.
\end{abstract}

Keywords: Moral Values, School, Religion, Education Values.

\section{A. INTRODUCTION}

The implementation of values education in schools has been under the spotlight of many researchers. The study of value education as a government policy in educating people's lives has been studied by many researchers. Educators of moral values in religious studies are considered to be similar and identical (Arthur, 2003). Teaching School education is actually helped by religious values and becomes a moral vehicle for education.

Many researchers still encounter difficulties in developing values education. Teachers do not have the skills to integrate values in learning at school (2015), although teachers should be role models for students (Bradly, 2011). Many cases are about morals (Walker, 2013; Zagzebski, 2017). Research with exemplary morals reveals what can be obtained naturally. Morals can also be disseminated to others as research by scholars (Kohlberg, 1981, which focuses on justice and moral cognition (Giligan's, 1982). He focuses on promoting ethics of care and Hoffman (2000) emphasizes empathy.

Researchers seek to study morals as an interest in education (Jones \& Corley, 2005). While there are also those who take advantage of the idea of moral excellence in education (Colby \& Damon, 1992). Matsuba is interested in seeking morals from 
ordinary people who are role models (Matsuba \& Walker, 2004). While there are those who occupy morals proportionally (Fleeson et al., 2016).

Compared with previous research, this study reveals how value education is to students in industrialized societies. This research was conducted in Cidenok Village, Sumberjaya District, Majalengka Regency. With this background, research on how student value education in an industrial society becomes interesting and important to be analyzed in more depth.

Education plays an important role for the survival of human life, with human education becoming more focused in carrying out their lives, wiser in making decisions and providing opportunities to shape a better life in the future. Consciously or not, humans cannot be separated from the role of education. When humans are born in the world, they first get education from their parents, then from their family and environment.

Education can bring big changes in the history of human civilization. Due to education, a person begins to change in thinking patterns, ways of interacting, getting education, as well as in developing regional progress. An educated person will think rationally that all problems in society must have a solution point. Because to realize these potentials students are encouraged to be active and enthusiastic in shaping and developing their potential, so that later students can have religious spiritual strength, have noble morals, form self-control, hone intelligence, and have skills that will bring benefits to themselves, and also for the community (Aminoto, 2003).

This research was conducted in Cidenok Village, Sumberjaya District, Majalengka Regency using a qualitative approach. The method used is descriptive method. Data mining was carried out using in-depth interviews with informants.

\section{B. LITERATURE REVIEW}

Value education has been studied by many experts such as Lickona (2004; Yildrim \& Dilmac, 2015; Cavus, 2015). Lickona Many experts try to describe the concept of value and value of education. Lickona described grades as what they appear to be. Value becomes a form of behavior, while Yildrim \& Dilmac see value as related to human emotions, thoughts and behavior.

By definition, characters have the same meaning with morals. Both are defined as actions that occur with full awareness that are ingrained in the mind, and in other words, they can be called habits. As revealed by Rachmat Djatnika (1996) that the word moral plural from the word khuluk which means "good character", is synonymous with ethics and morals. Character development in the education system is a relationship between character components that contain behavioral values and are interconnected between knowledge of behavioral values with strong attitudes or emotions to implement them, both towards Allah SWT, himself, others, the environment, the nation and the state as well as the international world. Character development is expanded in the form of character education. Meanwhile, character education is an investment of cultural values that builds the character, 
morality and personality of society which is carried out for a long time, continuously, intensely, constantly and consistently. Thus character education provides students with knowledge, knowledge, behavioral cultural practices that are oriented to the ideal values of life, both those originating from local culture (local wisdom) and external culture (Indra, 2010:27).

From an academic perspective, character education is defined as value education, character education, moral education, character education, which aims to develop the ability of students to make good and bad decisions, maintain what is good, and realize goodness in everyday life wholeheartedly. Therefore, the psychological content of character education includes dimensions of moral reasoning, moral feeling, and moral behavior (Lickona, 1992). Character education has the same mission as moral education and moral education. Conceptually, the words morals and morals have similar meanings, namely that both talk about human actions and behavior in terms of good and bad values. However, in its application, morals are more at the philosophical theoretical level as a reference for studying the value system, as stated by al-Ghazali (Djatnika, 1996) that temperament is a characteristic that remains in the soul from which actions arise easily and do not require mind. Meanwhile, morals are more directed at the aspect of benchmarks for judging one's actions. As stated by Djatnika, moral is the feeling that something is good or something is bad.

Likewise character education talks about human actions and behavior in terms of good and bad values. It's just that character education emphasizes the application of positive values in everyday life and does not just teach children what is right and what is wrong, but character education instills habits (habitution) about what is good so that students understand, are able to feel, and want to do good. In line with the above, Doni argues that character education in schools refers to the process of cultivating values, in the form of understandings, procedures for caring for and living these values, and how a student has the opportunity to be able to practice these values in a real way (Koesoema, 2010).

In terms of the meaning of character education, Darmiyati (2009) argues that character education actually has a higher meaning than moral education, because it is not just teaching what is wrong, more than that character education instills habits (habituation) about good things so that students understand (cognitive domain) about what is good and wrong, able to feel (affective domain) the value of good and usually do it (behavioral domain). Thus character education must be instilled in ways that are rational, logical, and democratic.

In the context of the life of society, nation and state of Indonesia, it is believed that the values and characters are implicitly formulated as the function and purpose of national education. This shows that these character values become targets for students to be able to face life's challenges at present and in the future.

The originator of character education which emphasizes the ethical-spiritual dimension in the process of personal formation is the German pedagogue FW Foerster (Muslich, 2011) Character education is a reaction to Rousseauian natural 
pedagogy adultery and Deweyan pedagogical instrumentalism. More than that, the puerocentric pedagogy through the celebration of the spontaneity of children (Edouard Claparède, Ovide Decroly, Maria Montessori) that characterized Europe and the United States in the early 19th century is now considered insufficient for the intellectual and cultural formation of an individual. The anti-positivist and antinaturalist polemic in Europe in the early 19th century was a liberation movement from natural determinism to a spiritual dimension, moving from personal formation with a psycho-social approach to a more integral ideal of humanism. Character education is an effort to revive the ideal-spiritual pedagogy that was lost by the waves of positivism in perspective of Comte.

\section{METHOD}

This research was conducted at societies in Village of Cidenok, Majalengka, Indonesia. The research is qualitative descriptive, with a in depth interview approach. The data that was collected in this research were analyzed using descriptive qualitative analysis techniques.

\section{RESULT AND DISCUSSION}

Based on the results of the interview, it can be concluded that the tradition inherited by the people of Cidenok Village is related to value education and does not contradict the teachings of the religion they profess, namely the teachings of Islam. Because in fact the teachings of religion and the beliefs they profess do not contradict each other, but instead support one another.

The community has its own guidelines for socializing with other communities. The community strives to maintain its values with its natural environment. In the understanding of society, the existence of the state, religion, and tradition must be balanced, so that a balance within indigenous peoples can be formed. As an indigenous community, traditions cannot be separated in the life of the community, because it is a unity that complements one another. Although modern cultures have started to enter indigenous peoples, they have not completely changed the traditions that exist in them. This is because the community still maintains their local wisdom in carrying out daily life, and carries out traditional socio-culture that refers to the teachings of Religion.

Social values are a right held by a community, especially in indigenous communities, which become the basis for behavior. Social values are also the differentiator between good and bad, appropriate or inappropriate which is obtained through the weighing process. This is of course influenced by the culture that has long been embraced by the community.

For indigenous people, there are values that become a philosophy of life and have become ingrained in the lives of their citizens, and grow and develop in people's lives so that they become identities and characteristics that distinguish these communities from other communities. 
Society has a pillar of life that leads them to a prosperous life. Intention becomes a person's starting point in doing everything, this is then reflected in his words and behavior, resulting in an adjustment to the three. The incompatibility between the three pillars will give different meanings in society, so that it makes humans inconsistent with what they want or other words in other hearts also in behaving, which is called hypocrisy. In the community itself highly upholds courtesy and manners. So that in behaving and in a language they are always careful with whom they speak, there are different grammar uses for older people, peers, and younger people.

Character education in students can be seen from the development of religious values socialized from mosques, schools and madrasas (diniyah). This education begins with how to speak or say. When speaking they will be careful and use good grammar, so that there will be no offense or misunderstanding of others. Every word must be expressed politely to everyone, whether you are a relative or someone else. This creates a sense of togetherness for each other, has a sense of mutual respect, and encourages people to protect and help one another, so that a harmonious life can be realized.

People in carrying out our social life have a mutual respect for each other. Like when speaking, we must be careful, and pay attention to the situation and with whom our opponent is talking. Every word used in speech must be expressed politely to anyone, whether to parents, siblings, other people, even to nonindigenous communities. As expressed by the community. As a member of the community who still adheres to customs, of course, in their activities they will not be separated from the customs. However, because the majority of people embrace Islam, of course, before starting to do something, it must first be considered so that it does not conflict with the other two sources of law. If there are differences in stance, it must be discussed by involving all residents.

The community is very thick with cultural values, they together preserve the customs that have been passed down from their ancestors from generation to generation. Like when the harvest season arrives, before starting the harvest, it must be started with the reading of the Prayer beforehand which is carried out simultaneously, this is intended to ask permission to start the harvest and ask for personal safety. However, due to differences of opinion so that some of the members of the community violate them, that person will be penalized for their actions according to their mistakes.

Everything we do has its respective sanctions, if we do good then we will get good too, and if we do bad things will also be repaid badly to those who do it. Every indigenous community must obey all the rules contained in it, in addition to following every customary rule they must also respect everything that affects their life, such as nature and the environment. If there are indigenous people who violate these rules, they will usually get calamity or better known as catastrophe, for the punishment given by nature to that person. In addition, they will also get sanctions that have been determined. 
Positive value education in society is also related to the value of loyalty and exemplary. This society has a very strong obedience to their leaders, because according to their understanding, if they do not obey orders, they will be disastrous and will not get the blessing of life. In electing their leader, the community usually chooses.

In social life, it must not be separated from a process that leads to the development of a society. The developments that occur in this society include elements such as geography, biology, economy, technology, culture and education. These aspects are also very supportive of the changes that are taking place in society. The more the times are developed, the more sophisticated the technology, of course, the more changes in the mindset in society. The mindset of the community that has changed does not mean that the culture in the area has also changed, but there are values that are considered in carrying out the socio-culture in that community.

Cidenok Village Education Leader, Dr. H. Moh. Dulkiah, M.Si, stated that society has started to develop in the field of education, this can be seen from the enthusiasm of parents who send their children to school. In the past, residents rarely left the Cidenok environment, so that the community only received elementary and junior high school education, and it was very rare to continue to junior high school level. The reason parents do not send their children to high school level is because it is very far away, and even then there is only one level, and the location of the school in the sub-district.

Apart from the change in people's mindset, it is also supported by other aspects such as the establishment of many schools, many people already have cellphones as a source of information, and many people can ride motorbikes. Local wisdom that is still preserved in the community still preserves the customs inherited from their ancestors. Wherever they are, and wherever they have migrated, they always give their distinctive identity as Cidenok residents

The majority of people who are farmers really appreciate natural products, especially rice. It is not surprising that in elementary education there are also local subjects related to farming, where students are taught the basics of agriculture, so that at least students know how to farm when they graduate from elementary school. And this is also mandatory, which has been given by Cidenok to all elementary schools in the community area.

However, when compared to the past, now education is much better. This can be seen from the many educational facilities that have been provided by the village government, as well as social media that have started to enter this area, so that the mindset of the people has also begun to be open to education. The economy of the community is not as difficult as it used to be, because now it is not uncommon for people to go abroad to make ends meet, thus supporting the community to continue their studies to a higher level.

The existence of the Covid-19 pandemic is an obstacle in teaching and learning activities, especially because the homes of students are located far away from the center of government. Another problem is that not all students have 
cellphones as a tool for online learning activities. The factors that become obstacles to the collective consciousness of the community are caused by the ingrained mindset of the community that ignores education. The community assessed that when compared to going to school, a child who helps with his parents' work in a factory is more clearly visible than going to school. Especially for girls who are seen as not needing to receive higher education, especially since factories currently accept more female employees.

The problems that cause unequal education are caused by economic factors. Indeed, the majority of people have a middle to lower class economy, of course it becomes an economic burden for parents in sending their children to school. Although the government has issued a 12-year Compulsory Education decision, which eliminates school fees up to the senior level, there are other economic burdens that parents must bear in sending their children to school, namely transportation costs and children's pocket money.

One of the obstacles in value education is that there are naughty children who influence other children. In addition, problems in elementary level are also related to the lack of interest in student learning due to economic problems in their families. Of the elementary school graduates, only about 50 percent continue their education to the junior high school level, this is because most of the elementary school graduates go straight to work abroad to become domestic helpers.

The problem in junior high school not much different from that in elementary school namely the lack of local male teaching staff. This junior high school teacher in Cidenok Village is not a native teacher from this area, but is drawn from various backgrounds. Some come from primary school teachers, and some are loan teachers from other junior high schools. In addition, they are also not junior high school teachers by profession, because there are also people who graduate from high school and then become honorary teachers.

\section{E. CONCLUSION}

The quality of public services for population administration and civil disability for citizens in need at the DISDUKCAPIL of Ambon City is in an adequate condition, especially from three dimensions: 1) The responsibility of employees to provide services appropriately and correctly according to the type of service promised to the community; 2) Employee insurance provides services, through knowledge or insight, courtesy, courtesy, self-confidence from the government, and respect for the community; 3) Employee empathy in providing services, willingness to approach, providing protection, and trying to find out the wants and needs of the community.

Meanwhile, there are three dimensions of public service quality that are still inadequate in the location of this study, namely: 1) Tangible service delivery, employee appearance and other physical facilities such as equipment or work that supports services; 2) Effectiveness of employees in providing services, through the

achievement of predetermined goals, both in the form of long-term targets and 
missions; 3) Efficiency of employees in providing services, applying good working methods (light, easy, inexpensive, and short ways of working.

Four aspects or dimensions of employee professionalism in providing public services, which support the quality of public services in this study: namely: a) Employee knowledge of service mechanisms and procedures, b) Employee skills in providing services to residents in need, c) The ability of employees to provide services to citizens who need, and d) Experience of employees providing services. While the two aspects of employee work professionalism that do not support the three dimensions of public service quality at Ambon City DISDUKCAPIL are: employee discipline factor in providing services to residents in need.

\section{REFERENCES}

1. Anderson, L. W., et al. (2001). A taxonomy for learning, teaching, and assessing: $A$ revision of Bloom's taxonomy of educational objectives. New York: Longman.

2. Arthur, H. (2003). Testing language Teachers. UK: Cambridge university Press.

3. Baabdullah, A. (2020). The Association Between Smartphone Addiction and Thumb/Wrist Pain: A Cross-Sectional.

4. Brooks, J. G., \& Brooks, M. G. (2001). Becoming a constructivist teacher. In A. L. Costa (Ed.), Developing minds: A resource book for teaching thinking (3rd ed., pp. 150157). Alexandria, VA: Association for Supervision and Curriculum Development.

5. Berger, A. A. (2000). Media Analysis Techniques. Yogyakarta: Penerbitan Universitas Atma Jaya.

6. Brubacher, J. S. (1978). Modern Philosophy of Education. New Delhi: Tata Mc. Brau Hill Publishing Company Ltd.

7. Colby, A., \& Damon, W. (1992). Some do care: Contemporary lives of moral commitment. New York: Free Press.

8. Colby, A., \& Kohlberg, L. (1987). The Measurement of Moral Judgment (Vols. 1-2). New York: Cambridge University Press

9. David, C. (1986). Tike the Road to Creativity. USA: Argus Communications.

10. Dominick, J. R. (1993). The Dynamic of Mass Communication. McGraw Hill, Inc.

11. Fleeson, W., Miller, C., Furr, R. M., Knobel, A., Jayawickreme, E., \& Hartley, A. (2016). Beacon Project white paper: What are the key issues for the study of the morally exceptional?. Wake Forest University, Winston-Salem, NC.

12. Gilligan, C. (1982). In a different voice: Psychological theory and women's development. Cambridge, MA: Harvard University Press.

13. Haralammbos, M., \& Horborn, M. (1995). Sociology Themes and Perspectives. London: HarperCollin Publisher.

14. Haydon, T., Hawkins, R., Denune, H., Kimener, L., McCoy, D., \& Basham, J. (2012). A comparison of iPads and worksheets on math skills of high school students with emotional disturbance. Behavioral Disorders, 37(4), 232-243.

15. Hilda, T. (1962). Curriculum Development, Terory and Practice. New York: Harcourt Broce dan World Inc. 
16. Hoffman, M. L. (2000). Empathy and moral development: Implications for caring and justice. Cambridge, UK: Cambridge University Press

17. Hollis, H. (2018). Information literacy as a measurable construct: A need for more freely available, validated and wide ranging instruments. Journal of Information Literacy , 12(2), 76-88. https://doi.org/10.11645/12.2.2409.

18. Koltay, T. (2011b). Information Literacy for Amateurs and Professionals: The Potential of Academic, Special and Public Libraries. Library Review , 60(3), 246257. https://doi.org/10.1108/00242531111117290

19. Kohlberg, L. (1981). Essays on Moral Development: Vol. 1. The Philosophy of Moral Development. San Francisco: Harper \& Row.

20. McLoad, W. T. (1989). The New Collins Dictionary and Theseaurus. Glasgow: William Collins Son.

21. Perry, J. A., \& Perry, E. K. (1991). Contemporary Society. New York: HarperCollins Publisher.

22. Dicken, P. (1998). Global Shift, Transforming the World Economy Ed ke-3. London: Paul Chapman.

23. Titus, H. H. (1996). Living Issues in Philosophy. New York: Litton Educational Publishing.

24. Walker, L. J. (2013). Exemplars' moral behavior is self-regarding. New Directions for Child and Adolescent Development, 142, 27-40.

25. Walker, L. J. (2014). Moral personality, motivation, and identity. New York: Psychology Press.

26. West, M. A. (1997). Developing Creativity in Organizations. USA: British Psychological Society.

27. Zagzebski, L. (2017). Exemplarist Moral Theory. New York: Oxford University Press. 